\title{
型枠内およびパイプ内におけるフレッシュコンクリートの 流動シミュレーション \\ FLOW SIMULATION OF FRESH CONCRETE IN FORM AND PIPE
}

\author{
渡辺健治*, 寺西浩司**, 森博嗣***, 谷川恭雄**** \\ Kenji WATANABE, Kohji TERANISHI, Hiroshi MORI and Yasuo TANIGAWA
}

\begin{abstract}
A new method for analyzing the behavior of fresh concrete, i. e., a viscoplastic divided space element method (VDEM) is proposed, which is applicable to simulate the flow and deformation of fresh concrete in practical concreting works, and some analytical results are shown in this paper. This method can be applied to calculate the large deformation of fresh concrete at casting in the form in which reinforcing bar and steel exist, and also to examine the effect of vibration. Such characteristics and applicability of VDEM are compared with the viscoplastic finite element method (VFEM) and the viscoplastic suspension element method (VSEM) proposed earlier by the authors.
\end{abstract}

Keywords : fresh concrete, rheology, flow simulation, viscoplastic divided space element method フレッシュコンクリート,レオロジー, 流動シミュレーション, 粘塑性空間要素法

\section{1.まえがき}

土地の有効利用，工期の短縮，労務者の不足などに対 する社会的要請から，コックリートの高性能化や工事の 合理化・省力化に関する要求が高まっている。これらの 課題に対して, 高強度・超高強度コンクリート, 高流動 コンクリート, 水中コンクリート, 纎維補強コンクリー トなどの新しいタイプのコンクリートが開発され,また, 圧入工法や無振動打設工法などの新工法が次々と試行さ れている。

フレッシュコンクリートの諸性質をレオロジーの観点 から整理し，その流動挙動を事前に予測する技術を確立 することは, コンクリート工事の合理化, さらには自動 化のための技術開発の基礎となるばかりではなく、「施 工設計 ${ }^{3)}$ の中枢を成す技術としても重要な課題である。

筆者らは，既に粘塑性有限要素法 (VFEM $)^{4), 5)}$ およ び粘塑性サスペンション要素法 (VSEM $)^{6,7)}$ を提案し, フレッシュコンクリートの各種レオロジー試験・コンシ ステンシー試験に関する解析を行い, 解析手法の妥当性 と適用範囲を示してきた。しかし,これらの手法は, 大
きな計算容量を必要とするため, 現段階では, 実際のコ ンクリート打設のような実用規模でのシミュレーション に適用するには至っていない。

本報では，上記の問題点を克服するだめ，実施工条件 下におけるシミュレーションが可能な解析手法（粘塑性 空間要素法) を提案する。また, 型枠内に打設されるフ レッシュコンクリートの流動挙動に関して, 同手法によ る若干の解析例を紹介し, 本解析手法の適用範囲や妥当 性を示すとともに，実験定数など解析に必要な入力情報 について検討する。

\section{2. 解析手法}

\section{1 概 要}

本報で提案する解析手法 (以下, 粘塑性空間要素法と 呼び，VDEM と略記）の概念を図一1に, VDEM およ びVFEM のフローチャートの比較を図一2に示す。

VDEM では, フレッシュコンクリートが流動すると 予想される空間全体を図一1(a) に示すように空間要素 （以下，要素と略記）に分割し，フレッシュコンクリー。

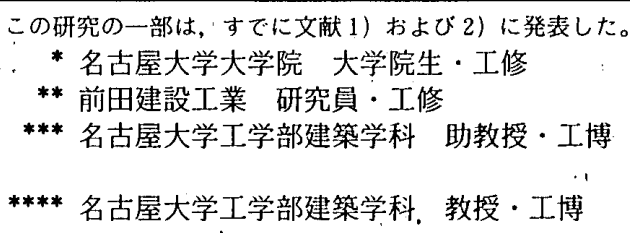

Graduate Student, Nagoya Univ., M. Eng.

Maeda Co., M. Eng.

Assoc. Prof., Dept. of Architecture, School of. Eng., Nagoya Univ., Dr. Eng.

Prof., Dept. of Architecture, School of Eng., Nagoya Univ., Dr. Eng. 


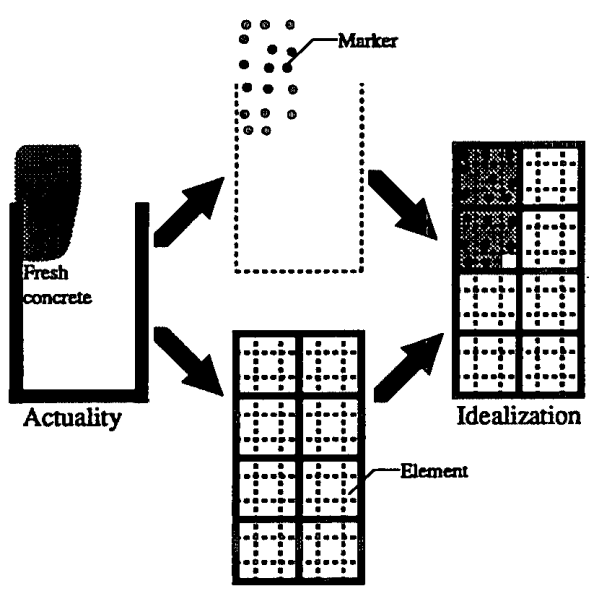

(a) 要素の作成手順

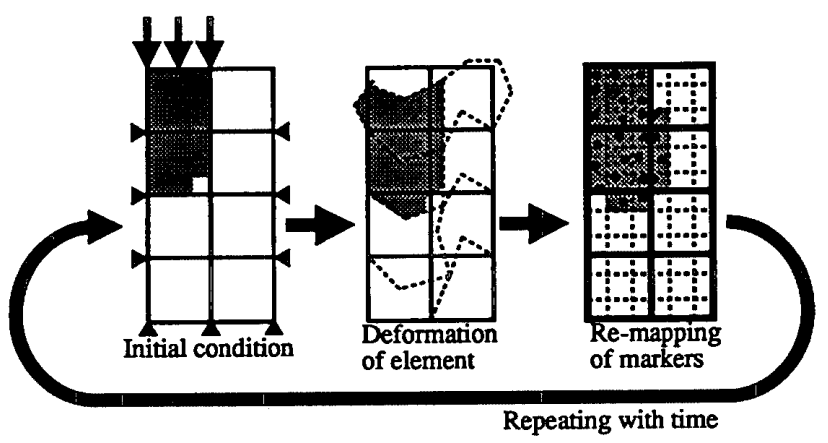

(b) 計算手順

图-1＼cjkstart粘塑性空間要素法の概念

トが存在する要素には仮想の浮子（マーカー）をランダ ムに配置する。マーカーが存在する要素には，ビンガム 流体の性質と自重を与え, その他の要素には, 粘性の非 常に小さい（後述の解析例では $1 \mathrm{~Pa})$ ニュートン流体 の性質を与える。この初期条件を用いて，先に提案した $\mathrm{VFEM}^{4), 51}$ と同様の粘塑性計算を行い, 節点変位量を求 める(図一1(b))。しかし, VFEM とは異なり, VDEM では, 図一1(b) に示すように, 節点変位量か ら各マーカー位置における変位量（流速ベクトル）を計 算し, マーカ一のみを移動させる。マーカ一は, 以前に 存在した要素の領域から別の要素の領域へも移動する。 ある要素の属性（コンクリートか非コンクリートか）は, その要素に存在するマーカーが存在するか否かに依存し ている。節点変位は計算の過程で求められるが, 実際に は節点は移動させない。この点が本解析手法の最大の特 徵であり, この処理によって, 要素構成にとらわれるこ となく，コンクリートの大変形 (流動) を表現すること が可能となる。

VDEM とVFEM の特徵の比較を表一1に示す。

\section{2 構成則}

一般に，フレッシュコンクリートは，ニュートン粘性 を示さず，ある大きさの偏差応力が作用するまで流動し ないビンガムモデルで表現し得ることが知られてい $る^{8)}$ 。Bingham が提案した降伏関数は, 単純せん断状態

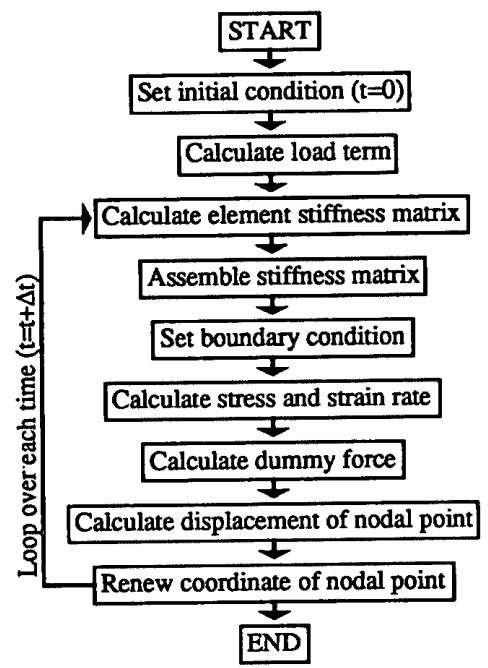

(a) V F EM

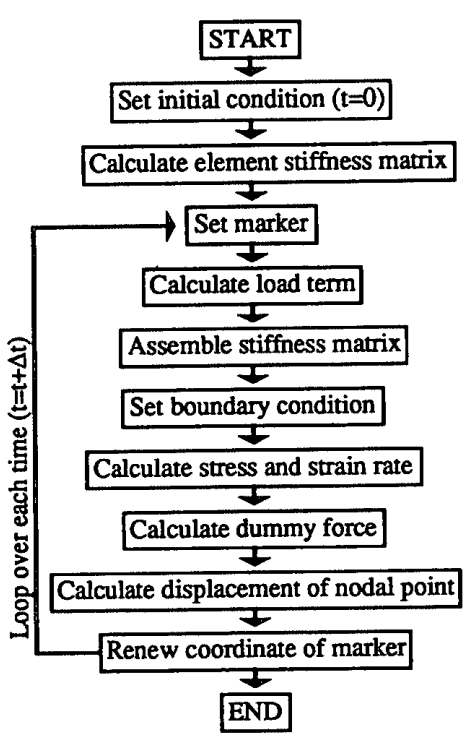

(b) VDEM

図一2 VFEM およびVDEM のフローチャート

にある粘塑性材料を表現するものであるが, VDEM で はVFEM と同様に, Hohenemser ・ Prager によって任 意応力状態に対して拡張された式を用いる 関数を図一 3 に示す。

筆者らは,フレッシュコンクリートの降伏関数として, 応力状態に依存した降伏条件を持つ複合モデルを提案し ており ${ }^{10)}$, 本解析手法もこの複合モデルに対応している が, 入力データが不足しているため, 本報告では応力状 態に依存しない条件 (ビンガムモデル) で解析を行った。 しかし，コンシステンシー試験などの小規模なシミュ レーションとは異なり，一般の施工条件下ではコンク リートの自重などによる応力がレオロジ一定数に比較し てかなり大きくなり，特に内部摩擦角が試料の流動挙動 に大きく影響することが考えられるため, 今後, 入力情 報の整備が必要と思われる。

\section{3 境界条件}

VDEM では, 節点を変位させずにマーカーの移動に 
表一1 粘塑性空間要素法 (VDEM) と粘塑性有限要素法 (VFEM) の比較

\begin{tabular}{|c|c|c|}
\hline Items & $\begin{array}{c}\text { Viscoplastic divided space element method } \\
\text { - VDEM - }\end{array}$ & $\begin{array}{l}\text { Viscoplastic finite element method } \\
\text {-VFEM - }\end{array}$ \\
\hline Input parameters & \multicolumn{2}{|c|}{ *Rheological constants of fresh concrete } \\
\hline Analytical method & $\begin{array}{l}\text { "Divide all space into elements and cells, } \\
\text { calculate whether fresh concrete exists in } \\
\text { each cell or not. }\end{array}$ & $\begin{array}{l}* \text { Divide fresh concrete into elements, and } \\
\text { calculate deformation of elements. }\end{array}$ \\
\hline $\begin{array}{l}\text { Description of } \\
\text { flow }\end{array}$ & *Displacement of markers. & isplacement of nodal points. \\
\hline Characteristics & $\begin{array}{l}\text { *Large deformation, separating and gathering } \\
\text { of concrete are easily analyzed. } \\
\text { *Aocuracy of solution depends on size of cell. } \\
\text { *Boundary condition is simple. }\end{array}$ & $\begin{array}{l}\text { *Applicable subjects are limited for restraint of } \\
\text { element construction. } \\
\text { *It is applicable to micro problem. } \\
\text { *Accurate solution can be obtained if deformation } \\
\text { is small. } \\
\text { *Boundary condition is complicated. }\end{array}$ \\
\hline
\end{tabular}

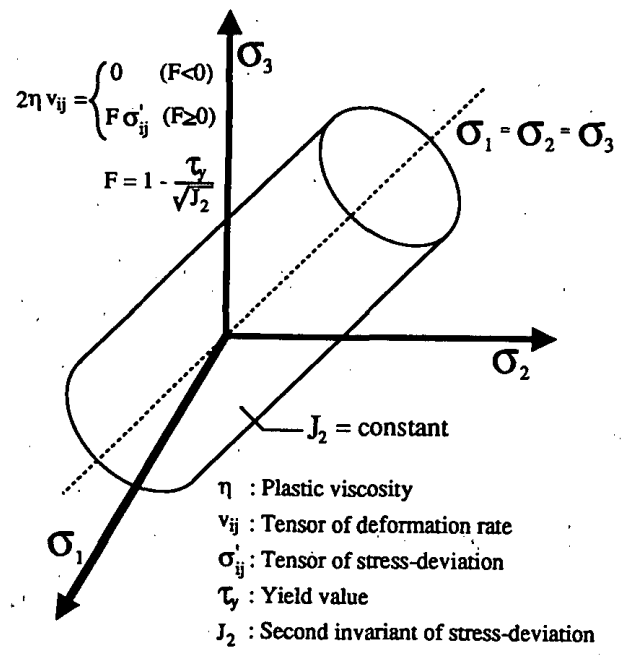

図一3＼cjkstart構成則之降伏関数

よってその流動挙動を表現しているため, VFEMに比 較して境界条件を簡単に設定することができる。また， VDEM では，垂直応力とすべりせん断速度の双方に依 存したすべり抵抗力を持つ境界節点を設けることによっ て, 試料と境界壁面の間に生じるすべり挙動を表現する ことができる。すべり抵抗力に関するレオロジーモデル および構成則を図一 4 に示す。VDEM では, 流動をマー カーによって表現することから，ある要素の一部の節点 が固定されている場合でも，図一5に示すように，その 要素が変形すればマーカーは移動し, 壁面近傍の空間要 素のサイズや性質を調整することによって疑似的に壁面 におけるすべり挙動を表現することが可能となる。この 手法を用いると，境界条件を非常に単純化させることが できる。また， 3 次元壁体の前後面におけるすべり抵抗 力を, みかけのレオロジー定数の増加としてとらえるこ とによって，2 次元問題として解析することが可能であ り，大規模問題を比較的少ない計算容量で取り扱うこと ができる。後述の解析例では, 本解析手法のこの特徴を 生かして，フレッシュコンクリートの流動挙動を小規模 な計算能力で再現することに重点を置いている。本報で は,すべり挙動などの局所的な現象を考慮していないが,

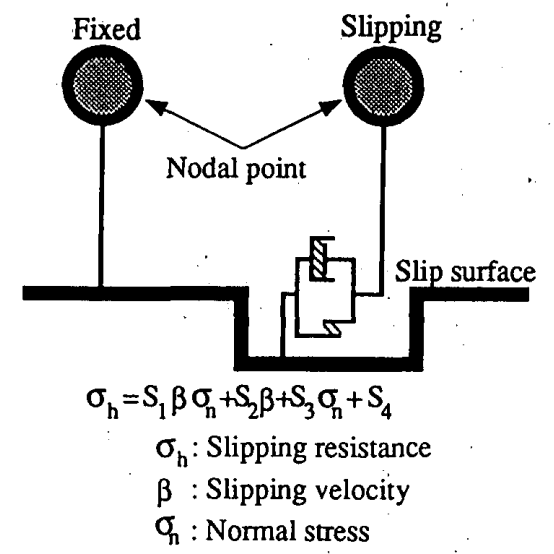

$\mathrm{S}_{\mathrm{p}} \mathrm{S}_{2}, \mathrm{~S}_{3}, \mathrm{~S}_{4}$ : Experimental parameters

図一4 すべり挙動に関する構成式
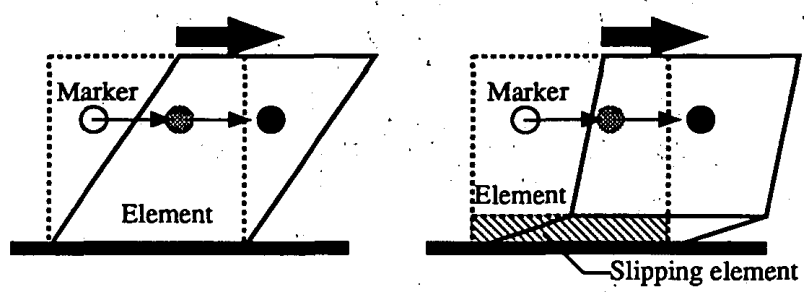

（a）すべりに関する性質を”（ｂ）すべり要素を別に設けた場合 要素に含ませた場合

図一5ＶVDEM 固有のすべり挙動の表現方法

入力データが整備されればより精度の高い解析を行うこ とができる。

\section{3. 解析結果とその考察}

3.1 部材の形状・寸法が流動挙動に及ぼす影響

先に提案した粘塑性サスペンション要素法 (VSEM) では, 骨材寸法を解析上の最小単位としており，コンク リートの流動挙動を正確に表現することができる反面, 計算量の関係から事実上は小規模な対象しか取り扱うこ とができなかった。VDEM は，VFEM と同様にフレッ シュコンクリートを均質体として取り扱っているだめ, 空間要素の大きさを解析対象に合わせて任意に設定する ことができる。また，境界条件に関してはVFEM より 
高い自由度を持っているなど, 両解析手法の長所を兼ね 備えている。

図一6および図一7に梁型枠へのコンクリート打設に 関するVDEM シミュレーション結果の一例を，また， 図一8に実大規模の壁状型杂への打設に関するVDEM シミュレーション結果の一例を示す。

いずれのシミュレーションも同一の解析プログラムと パーソナルコンピュータによって計算されたものであ る。鉄筋やフランジおよび開口部の下面における充填性 などの局所的な問題を取り扱う場合は，周辺のコンク リートの流入状況を再度入力データとして, クローズ アップされた領域のみを再度細かい分割の要素を用いて シミュレートし直すことも可能である。ただし，要素サ イズの大小とコンクリートのレオロジー定数の入力值は 無関係ではない"1)。コンクリートの変形性質は複合材料 としての見かけのものであり，取り扱うサイズに依存し
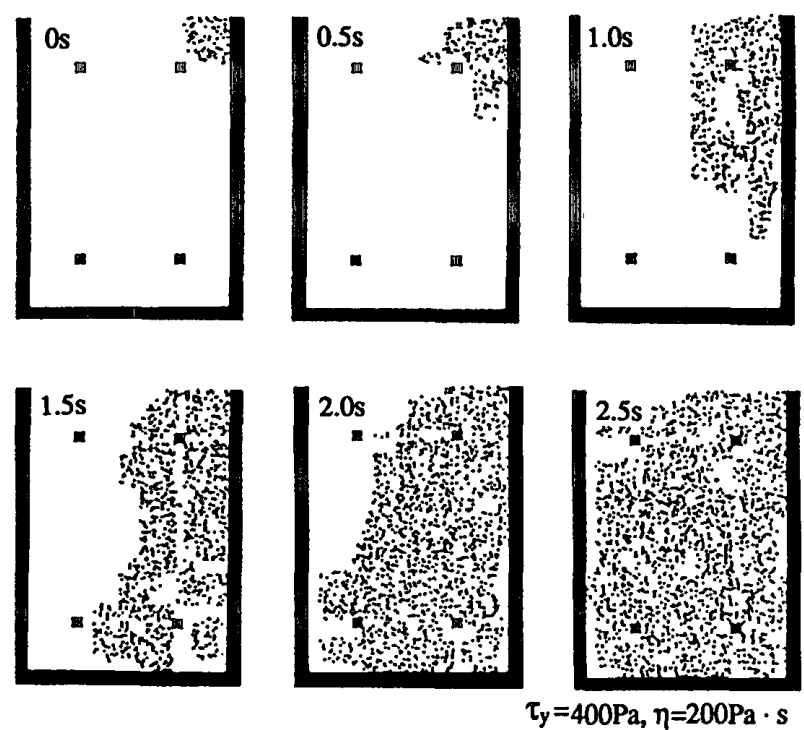

图一6 RC 梁断面内での流動挙動（解析結果）
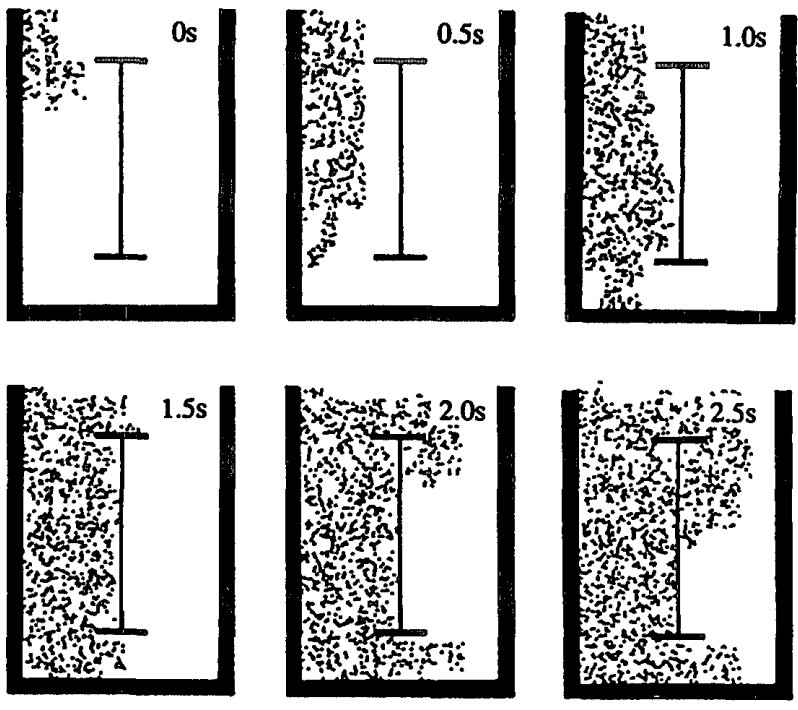

$\tau_{y}=400 \mathrm{~Pa}, \eta=200 \mathrm{~Pa} \cdot \mathrm{s}$

图一7 SRC 梁断面内での流動举動（解析結果）
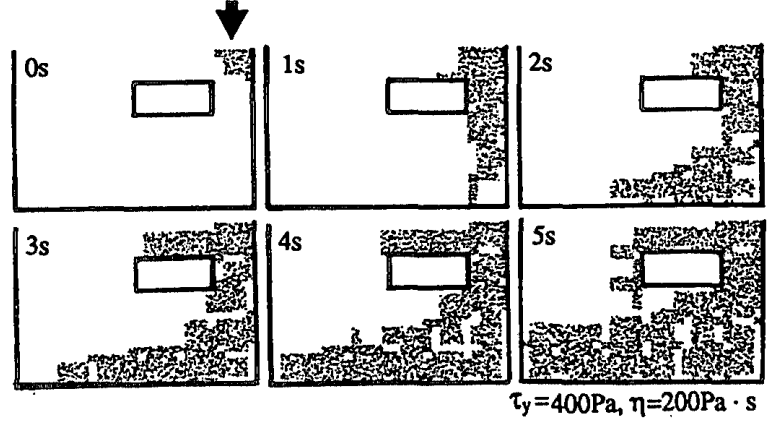

(a ) 型枠上部からの打設

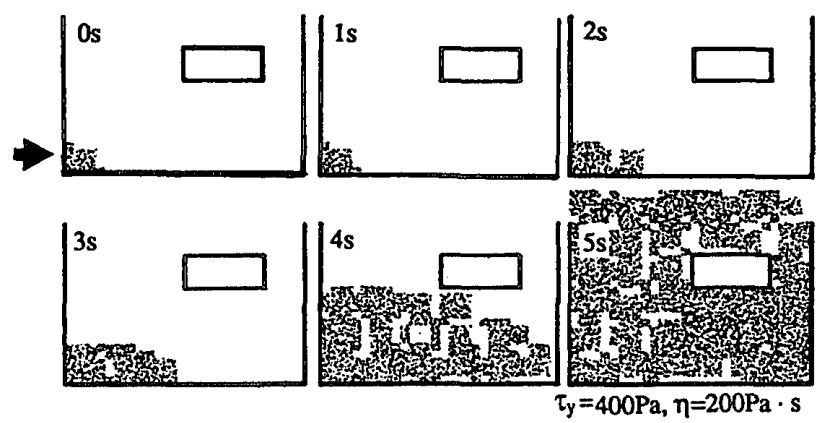

（b）型枠下部からの圧入打設

図一8 打設位置が流動挙動に与える影響（解析結果）

ている。この問題に関する入力情報は現在皆無であるが, 前述の VSEM などの解析結果と組み合わせたシミュ レーションが将来的には必要になるものと思われる。

\section{2 打設方法が流動挙動に及ぼす影響}

VFEM では，フレッシュコンクリートを連続体とし て取り扱うため,ポンプ吐出口を移動・停止させる場合, 障害物なビでコンクリートがちぎれ，再度結合する場合， コンクリートの打設容積が変化する場合などのシミュ レーションを行うことが極めて困難であった。VDEM では, マーカーによってコンクリートの存在を表現する ことから, 打設位置の要素に対して節点力 (圧力) やマー カーの発生条件などを設定することによって，打設位置 や打設時の圧力・速度などを考慮した施工シミュレー ションを行うことが可能である。

ポンプの昍出口を移動させながら打設した場合のシ ミュレーション結果の一例を図一9に示す。この例では, 打設口を每秒 $30 \mathrm{~cm}$ で左方へ移動させることによって, 比較的硬練りのコンクリートでもコンクリート上面の傾 斜角が小さくなり, 施工効率が改善される様子を確認す ることができる。

\section{3 振動・配筋の取り扱い方法}

3.1 で示した解析例のように, 型枠内の鉄筋・鉄骨な どの障害物を直接考慮することも可能であるが, VDEM では空間要素の性質を制御することができるた め, 流動抵抗や流動促進効果を特定の部位の性質として 与えることができる。ただし，この場合も，振動や配筋 

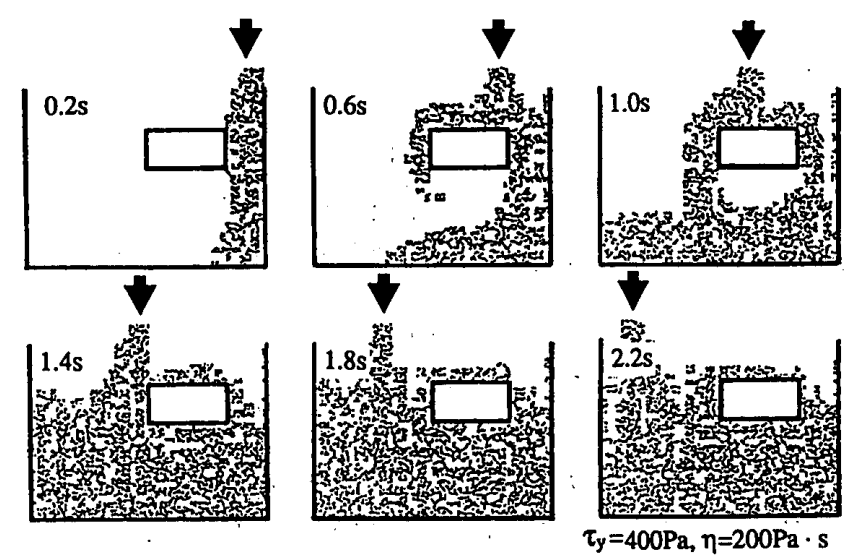

図一9打設口を移動させた場合の打設

などの条件によるみかけのレオロジー定数の変化性状を あらかじめ把握しておく必要があるが,この種のデータ は非常に少ないのが現状である。

筆者らは，みかけのレオロジー定数の測定を行うため に，配筋や振動が流動挙動（みかけのレオロジ一性質） に与える影響について既に実験的検討を行っている ${ }^{12\}}$ 。

VDEM による解析および実験結果の比較の一例を図 -10に示す。図中の点および線は，それぞれ解析およ び実験の結果を示しており，本解析が実験結果を十分な
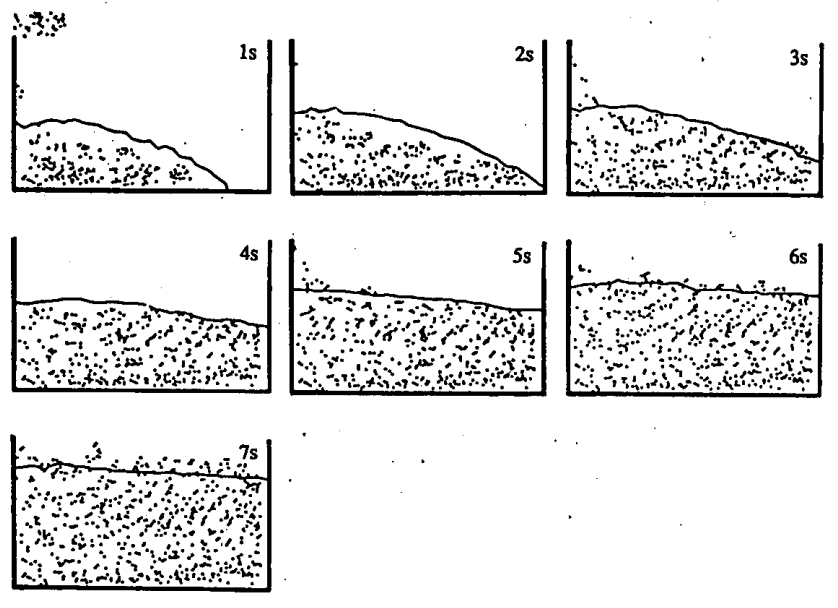

（a）無筋・加振の場合
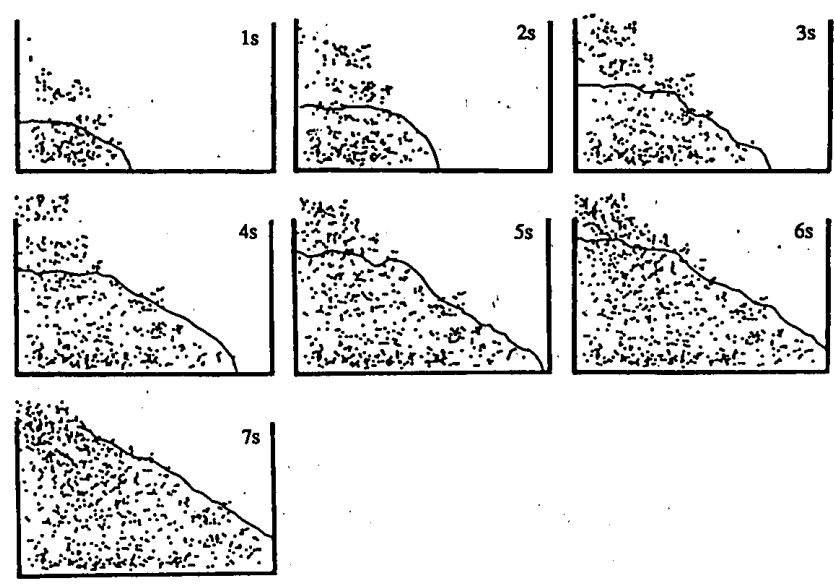

（b）配筋・無振動の場合

図一10 配筋・振動の有無による流動挙動の変化

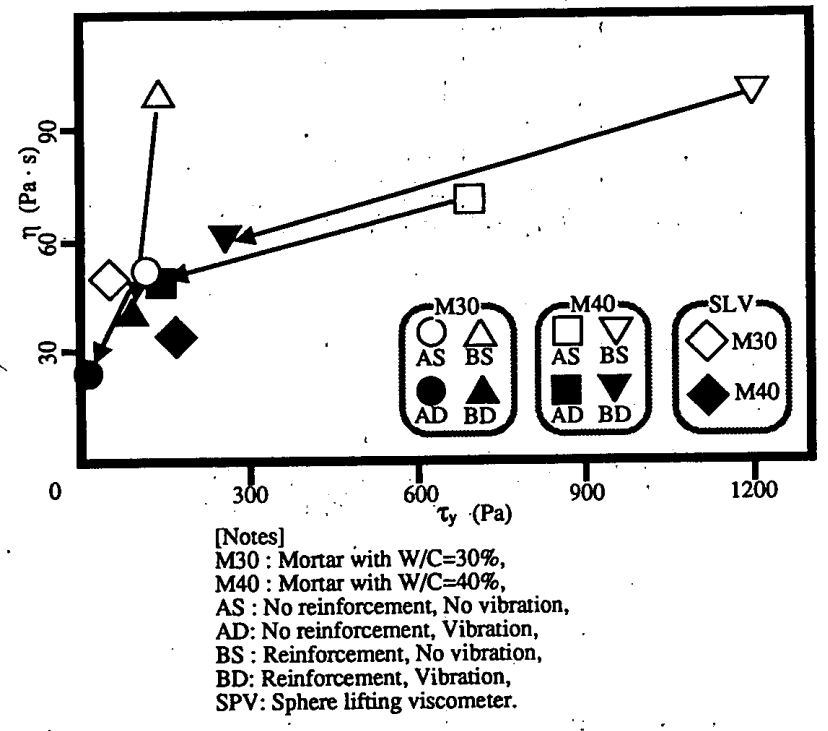

图一11.レオロジー定数の分布

精度でシミュレートしているごとがわかる。図一11に， 各条件下における武料のみかけのレオロジー定数を示 す。配笳によって流動抵抗が増すにつれて，みかけのレ オロジー定数 (降伏値 $\tau_{y}$ および塑性粘度 $\eta$ ) は増大する。 また，無振動加ら振動への変化に着目すると，一般に， 加振することにようて $\tau_{y}$ が大幅に減少するが，鉄筋を 配置した型枠では $\eta$ の減少も顕著である。これらの実 験結果を実施工シミュレーションの入力情報として還元 し，配筋や振動による影響を疑似的に考虑することが可 能となるが，反面，求められる入力パラメータとしては 各種条件下におけるバリエーションを網羅する必要があ る。

\section{4 鋼管内の充填状況およびポンプの圧力損失の予測}

一般の $\mathrm{RC}$ 部材では, 型枠を除去じた後コンクリー 卜の不充填部に対して事後修復することができるが，鋼 管充填コンクリートの場合は，その充媜状況を確認する ことは困難であり, 施工性の合否判定が難しい。また, 直管やテーパー管なよ゙の場合は，その圧力損失を理論的 に計算することが可能であるのに対して：この種の構造 に用いられる鋼管は径が大きく細管の層流理論を適用す ることが難しく，また内ダイヤフラムなどの障害がある 場合も多く，珐入打設の際の圧力損失を算定するために は数值解析による予測が有効な手段の一つとなる。

VDEM を用いた鋼管充填シミュレーションの一例を 図一12 に示す ${ }^{12}$ 。この解析では, ダイヤフラムの開口 面積を変化させ，この值が圧力損失に及ぼす影響につい て調べた。試料上面の形状にプラグフロ一現象がみられ， 内ダイヤフラム下部に空隙が残りにくい状況を示してい る。また解析より得られた有効開口面積率 $\left(\mathrm{D}^{*}\right.$ ：珐力 および流量に相当する理想管の径を実際の管径で除した 值) と実際の開口面積率 (D：ダイヤフラムの開口面積 を管径で除した値）の関係を図一13に示す。同図中の 

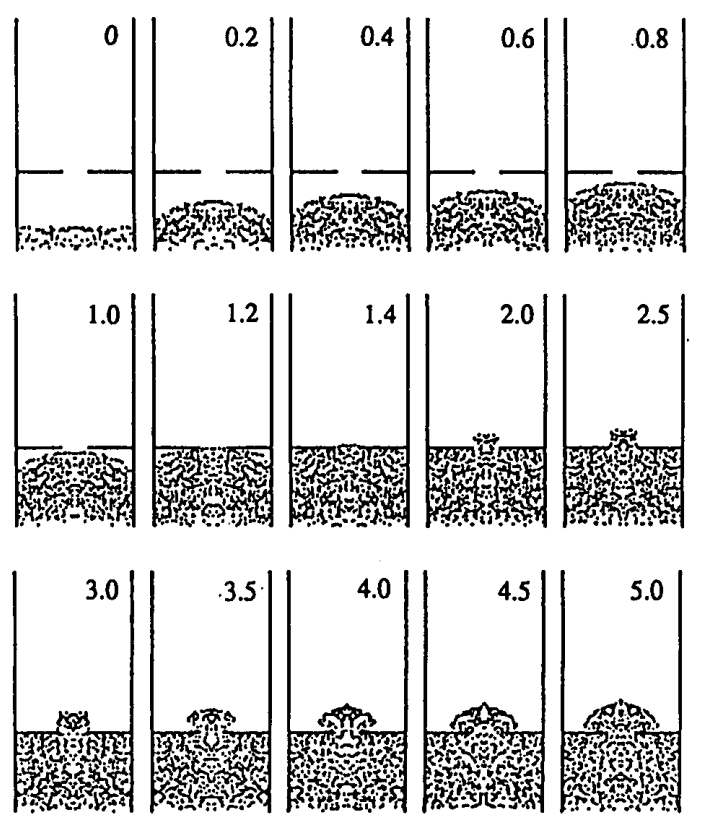

$\mathrm{D}=6 \%, \tau_{y}=400 \mathrm{~Pa}, \mathrm{~h}=100 \mathrm{~Pa} \cdot \mathrm{s}$

(a ) $\mathrm{D}=6 \%$ の場合
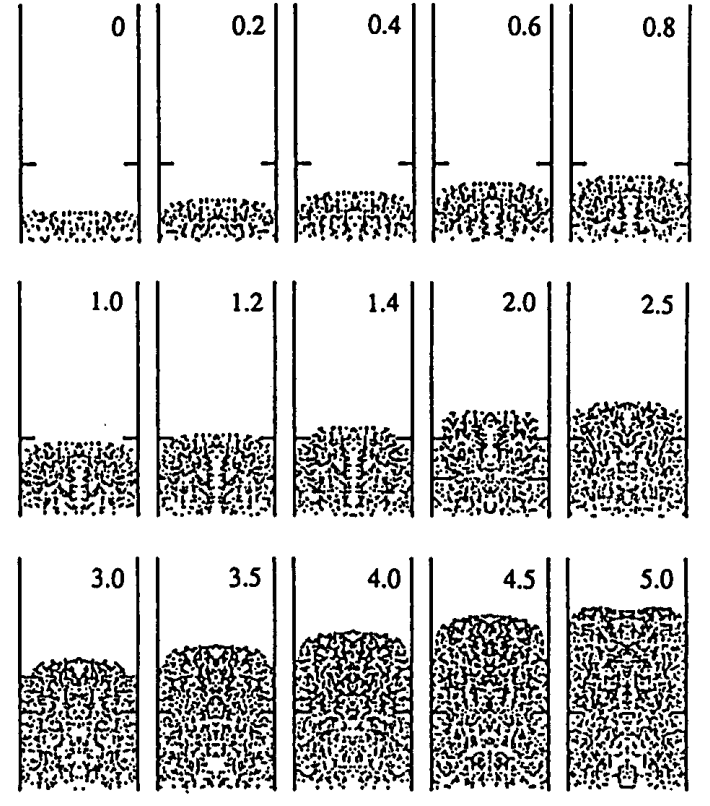

$D=56 \%,{ }^{\tau} y=400 \mathrm{~Pa}, \mathrm{~h}=100 \mathrm{~Pa} \cdot \mathrm{s}$

[Unit : s]

(b) $\mathrm{D}=56 \%$ の場合

図一12 鋼管内での試料の流動状況

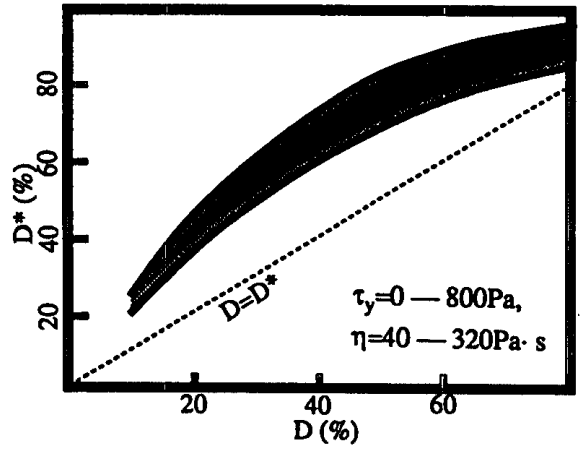

図一13 有効開口面積率 ( $\left.\mathrm{D}^{*}\right)$ と開口面積率 (D) の関係

一点鎖線は，ダイヤフラムによる圧力損失が，開口部と 同じ径の円管の理論解 ${ }^{13)} に$ 相当することを示している。 同図より明らかなように，実際の開口面積率 (D) に比 べて有効開口面積率 $\left(D^{*}\right)$ は 20 - 30\% 程度大きな値 となっており，ダイヤフラムを持つ鋼管の圧力損失は, その開口部と同径の直管よりは小さいことが明らかと なった。

\section{4. 本解析手法の位置つけ}

コンシステンシー試験のシミュレーションに実績のあ る粘塑性有限要素法（VFEM）を基準に考えると，図 一14に示すように，粘塑性サスペンション要素法 (VSEM) は，粗骨材相互の接触などを詳細に考慮し たミクロな解析に適しており，逆に本報で提案した VDEM は，フレッシュコンクリートの諸性状を単純化 させたマクロな解析手法として位置づけることができ

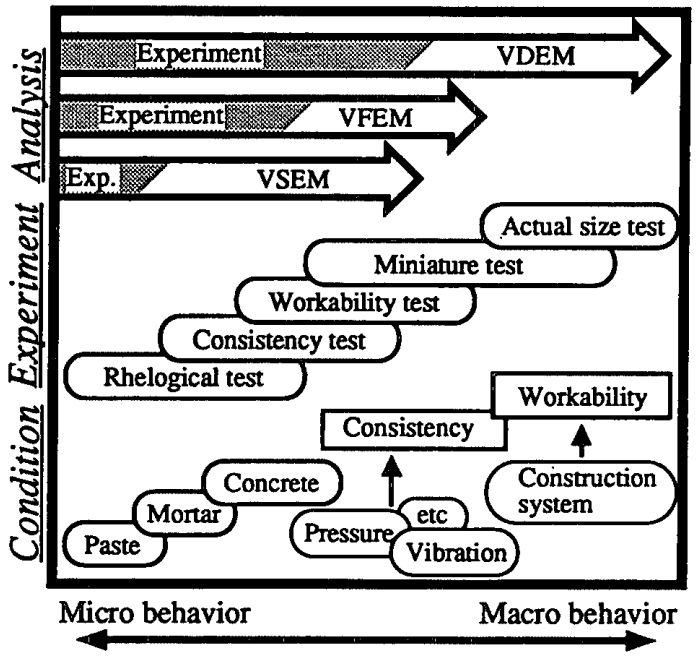

図一14 VDEM 解析手法の位置付け

る。VSEM ではペーストレベルのレオロジー定数を入 力值とした解析が可能であるのに対し，VFEM ではコ ンクリートのレオロジー定数が，またVDEM では施工 条件を加味した入力值が必要となる。一方では, VSEM がレオロジー試験, ワーカビリチー試験および 模型実験などの小規模なシミュレーションにしか適用で きないのに対し，VDEM では模型実験や実大施工を効 率よくシミュレートすることが可能となる。

以上のように, 実験データの整備状況に応じて各種の 解析手法を適宜選択し, 要求される解析精度を満足させ ることが可能となる。

また, VSEM によって得られたミクロな数值解析の 結果を VFEM の入力値として用い，さらにその出力結 
果をVDEM の入力值として用いることが可能である。 このような利用形態は, 各解析手法の長所を組み合わせ た合理的な方法といえる。

\section{5. まとめ}

本研究では，フレッシュコンクリートの流動解析手法 として粘塑性空間要素法 (VDEM) を提案した。また， 本手法を用いて，各種条件下におけるコンクリートの流 動挙動について解析し，その適用範囲と妥当性を示すと ともに, 解析に要求される入力情報について検討した。 本研究で提案したVDEM は，他の解析や実験から得ら れた情報に依存する割合が大きく，基礎物性のみの入力 情報では実用的な解析を行うことが困難であるが，新材 料および新工法が開発されるたびに，大規模な施工実験 が繰り返されている現状を考えれば，現行の施工実験の かなりの部分をシミュレーションに置き換えることが可 能であり，基礎的な実験デー夕を蓄積することによって VDEM 解析の有用性が高まるものと考えられる。

\section{謝 辞}

本研究費の一部は, 平成 4 年度文部省科研費 - 奨励研 究 (A), 同一般研究 (B), 同特別研究員奖励研究, 並び に牧田国際育英会学術研究助成金によった。付記して謝 意を表する。

\section{引用文献}

1) Tanigawa, Y., Mori, H. and Watanabe, K. : Flow Simulation of Fresh Concrete by Viscoplastic Divided Space Element Method, Proc. of the 33 rd Japan Congress on Materials Research, pp. 227 233, 1990. 3.

2) 谷川恭雄, 森 博嗣, 渡辺健治, 寺西浩司：空間要素法 によるコンクリートの打設シミュレーション,コンクリー 卜工学年次論文報告集, Vol. 14, No. 1, pp. 415 420, 1992.6 .
3）谷川恭雄, 森 博嗣：フレッシュコンクリートのコンシ ステンシー評価法, コンクリート工学, Vol. 25, No. 5, pp. 4 16, 1987.5 .

4) Tanigawa, Y. and Mori, H. : Analytical Study on Deformation of Fresh Concrete, Jour. of Engineering Mechanics, Proc. of ASCE, Vol.115, No. EM3, pp. $493 \sim 508,1989.3$.

5）森 博嘼, 谷川恭雄：粘塑性有限要素法によるフレッシュ コンクリートの流動解析, 日本建築学会構造系論文報告 集, No. 374, pp.1 9, 1987.4.

6) Tanigawa, Y., Mori, H. and Watanabe, K. : Analytical Study on Flow of Fresh Concrete by Suspension Element Method, Proc. of the RILEM Colloquium on Properties of Fresh Concrete, Hanover, pp. 309 316, 1990. 10.

7）森博呞, 渡辽健治, 梅本宗宏, 谷川恭雄：二相モデル を用いたフレッシュコンクリートの流動解析手法, 日本 建築学会構造系論文報告集, No. 427, pp. 11 21, 1991. 9.

8) Tattersall, G.H. and Banfill, P.F.G., : The Rheology of Fresh Concrete, Pitman Advanced Publishing Prog. ram, $356 \mathrm{pp} ., 1983$.

9）Fung, Y.C., : 固体の力学／理論, 培風館, $524 \mathrm{pp}$, 1970. 4 .

10）森 博嗣, 谷川恭雄：フレッシュコンクリートの構成則 に関する研究, 日本建築学会構造系論文報告集, No. 396, pp. 9 16, 1989. 2 .

11）江守一郎· Schuring, D. J. : 模型実験の理論之応用, 技 報堂, 255 pp. , 1974.

12）、谷川恭雄, 森 博嗣, 渡辺健治, 寺西浩司: 空間要素法 によるコンクリートの打設シミュレーション, コンクリー 卜工学年次論文報告集, Vol. 14, No. 1, pp. 415 420, 1992. 6 .

13）谷川恭雄, 森 博嗣, 野田 豊: フレッシュコンクリー トのポンプ王送性に関する理論的考察, コンクリート工 学年次論文報告集, Vol. 13, No. 1, pp. 203 208, 1991. 6.

(1992 年 12 月 28 日原稿受理, 1993 年 6 月 14 日採用決定) 